Article

\title{
Predicting and Explaining the Acceptance of Social Video Platforms for Learning: The Case of Brazilian YouTube Users
}

\author{
Patricio Ramírez-Correa ${ }^{1, * \mathbb{C}}$, Ari Mariano-Melo ${ }^{2}$ and Jorge Alfaro-Pérez ${ }^{1, *}$ \\ 1 School of Engineering, Universidad Católica del Norte, Larrondo, Coquimbo 1780000, Chile \\ 2 Department of Production Engineering, Universidade de Brasília, Campus Darcy Ribeiro Asa Norte, \\ Brasília 04457, Brazil; arimariano@unb.br \\ * Correspondence: patricio.ramirez@ucn.cl (P.R.-C.); jalfaro@ucn.cl (J.A.-P.); Tel.: +56-51-220-9899 (P.R.-C.)
}

Received: 8 November 2019; Accepted: 4 December 2019; Published: 12 December 2019

\begin{abstract}
This study aims to predict and explain the acceptance of social video platforms for learning. A research model is proposed that explains that the intention of using these platforms is based on the perception of performance, social influence, and hedonic motivation. To validate the model, 568 Brazilian YouTube users were surveyed. The data were analyzed with partial least squares structural equations modeling (PLS-SEM). In particular, the predictive power of the model was assessed using the PLSpredict procedure. The results of this study can help to understand and forecast the use of these platforms for learning in developing countries.
\end{abstract}

Keywords: e-learning; social video platform; PLSpredict; Brazil

\section{Introduction}

Social video platforms are embedded in the daily life of a large part of the planet's inhabitants. A social video platform (SVP) is defined as a website that allows its users to upload and share video clips with the broader public or with guests [1]. YouTube is the most popular platform of this type worldwide. YouTube users are almost a third of internet users, every month more than two billion users visit this platform, and every day more than one billion hours of video are watched on it. YouTube can be accessed in eighty different languages and is located in more than one hundred countries [2].

Unlike other social networking sites, SVPs are internet services where the user's social involvement is minimal [3]. This participation is mainly focused on the content exchange. This behavior has allowed them, over time, to become platforms to gather information and help to learn [4]. In fact, today, YouTube is the first source for learners when they want to learn something new $[5,6]$.

Although the literature has emphasized the value of SVPs as an educational source of information [7,8] —supporting informal and self-directed learning in a wide range of topics-there is a lack of knowledge about how these platforms are adopted as a medium of learning by their users [9]. One of the first attempts to understand this phenomenon was made recently by Chintalapati and Daruri [9] through the validation of Fred Davis' technology acceptance model (TAM) [10]. These authors propose that further studies evaluate additional variables which improve the explanation of the adoption of SVPs. The present study is oriented to advance in this sense.

If we consider that quality education is a fundamental challenge to support sustainable development throughout the world [11] and that one of the ways to achieve this objective is to extend the adoption of information technology which propitiate this goal [12,13], then the analysis of the phenomenon of SVPs as an educational space emerges as a key study topic.

Explanation and prediction are two main objectives of the development of theories about a particular phenomenon. On the one hand, the explanation is oriented toward the identification of the 
causal mechanisms underlying a phenomenon and, on the other hand, the prediction is understood as the ability to predict values for individual cases of that phenomenon. Moreover, while predictive models may not be based on causal mechanisms, an advanced level theory involves both understanding the underlying causes and prediction [14]. That is how the explanation of a phenomenon can be seen as the prelude to prediction. In this sense, and considering the enormous impact of the adoption or non-adoption of these technologies in society we pose the question: Is it possible to explain the use of SVP for learning? Are the variables that explain the adoption of SVP for learning in general useful for predicting individual cases? To answer these research questions this study focuses not only on explaining the adoption of SVPs as a medium of learning but on predicting the intention of their adoption based on an explanatory model developed from the previous literature.

In this context, this study aims to predict and explain the acceptance of SVPs for learning. To achieve this purpose, first an explanatory model of adoption is developed, and then its prediction capacity is validated with a sample of real data from users of SVPs.

The original contributions of this study are twofold. On the one hand, this study increases the existing knowledge about the adoption of SVPs incorporating two new variables that improve the explanation of the intention to use this technology for learning purposes. On the other hand, this study contributes to the assessment of the predictive power of a technology acceptance model, a contribution that is added to the limited existing research body which applies this type of analysis.

The results of the study should be interesting both to develop strategies aimed at improving SVPs for learning and to exemplify the evaluation of the prediction in a structural equation. Business readers might understand that increasing the quality and variety of the hedonic and social features of an SVP is an essential point of improvement in this technology for learning purposes. Moreover, academic readers could use the study methodology to evaluate the predictability of other models of human behavior.

The rest of this article has been organized as follows. First, a review of the literature on variables associated with the adoption of SVPs to learning is presented, which gives way to the proposed research model. Subsequently, the materials and methods are described, followed by the results of the empirical study. The article ends with a discussion of the findings and conclusions.

\section{Literature Review}

\subsection{Social Video Platforms for Learning}

Historically the advances of technology allowed people to unleash from time and space restrictions on learning and teaching. While printing was one of the first that impacted knowledge sharing, in our days, information technology determines the learning speed and options as self-learning. Consistent with the above, research has permanently addressed information technology adoption and acceptance in education [15-17], emphasizing the necessity for meaningful information technology inclusion in the educational setting [17]. In this sense, studies have recently addressed topics such as mobile learning [18], Moodle [19], Facebook [20], lifelong digital learning [21], personal learning environments [22], and multimedia technologies [23].

Today the impact on the education of social media platforms is a crucial element in information technology adoption research. This research has been developed around terms such as openness, interactivity, ubiquity, sociability, and either synchronicity or asynchronicity $[21,24,25]$. Thus, solutions like Wikis, Twitter, Facebook, Blogger, and YouTube are relevant constituents of these social media tools [26]. Among the many social media platforms available, special attention is given to the educational application of the SVPs, which mostly employ videos as a learning resource. For that reason, many studies emphasize positive intentions and the actual use of videos due to their inherent instructional affordance for the educational process. As a point of reference, Rosenthal refers to TED Talk, YouTube, and Vimeo; also, other options considered are Webinar [27] and MOOC [28].

Notwithstanding the expected content redundancy and the problem of finding the right educational video [29], YouTube is the most recurrent social video tool used in education [26]. In addition, it is 
one of the first sources for learners when they want to learn something new [5], and it is capable of enhancing the learning experience considering that video is significant to the subject at hand [30]. Four lines of research can be identified in the literature regarding the use of the YouTube platform in education: educational video quality [29,31]; self-directed and long-life learning [21,32]; the cultural dimension [7]; and acceptance and use [15-17]. In particular, regarding research into the acceptance and use of the YouTube platform in education, Table 1 describes valuable studies in this line. First, based on an extended model of TAM, Lee and Lehto [33] found that perceived ease of use was not significantly predictive of either perceived usefulness or behavioral intention. Second, using the unified theory of acceptance and use of technology (UTAUT) model, Jung and Lee [7] concluded that effort expectancy has no significant impact on the behavioral intention for student samples, both in Japan and the USA. In the case of educators, both in Japan and the USA, only performance expectancy has a significant impact on behavioral intention. Third, Chintalapati and Daruri [9] developed and validated TAM construct scales for the use of studying YouTube as a learning resource. Fourth, Bardakci [34] concluded that effort expectancy has no significant impact on behavioral intention. Finally, for the TAM model, Sheppard and Vibert [35] reached the conclusion that perceived ease of use has no significant effect on either perceived usefulness or behavioral intention, positing that perceived ease of use has a moderator effect on the relationship between task-technology fit and perceived usefulness.

Table 1. Acceptance and use of YouTube in education.

\begin{tabular}{|c|c|c|c|c|}
\hline Study & $\begin{array}{l}\text { Conceptual } \\
\text { Model }\end{array}$ & $\begin{array}{l}\text { Statistical } \\
\text { Analysis }\end{array}$ & Findings & Sample \\
\hline [33] & $\begin{array}{c}\text { TAM } \\
\text { Extended }\end{array}$ & SEM & $\begin{array}{l}\text { Not supported } \\
\text { PEOU affects PU } \\
\text { PEOU affects BI }\end{array}$ & 432 users \\
\hline [7] & UTAUT & Regression & $\begin{array}{l}\text { US and Japanese students } \\
\text { PE affects BI } \\
\text { SI affects BI } \\
\text { Japanese students } \\
\text { FC affects BI } \\
\text { US and Japanese educators } \\
\text { PE affects BI }\end{array}$ & $\begin{array}{l}569 \text { college } \\
\text { students and } 57 \\
\text { educators }\end{array}$ \\
\hline [9] & TAM & SEM & Validated TAM variables scales & $\begin{array}{l}\text { Study 1: } 140 \text { users } \\
\text { Study 2: } 200 \text { users }\end{array}$ \\
\hline [34] & UTAUT & SEM & $\begin{array}{l}\text { PE affects BI } \\
\text { SI affects BI } \\
\text { BI affects AU }\end{array}$ & $\begin{array}{l}319 \text { high school } \\
\text { students }\end{array}$ \\
\hline [35] & TAM & SEM & $\begin{array}{c}\text { Not supported } \\
\text { PEOU affects PU } \\
\text { PEOU affects BI } \\
\text { Supported } \\
\text { TTF impacts PU, modified by PEOU }\end{array}$ & $\begin{array}{l}247 \text { college } \\
\text { students }\end{array}$ \\
\hline
\end{tabular}

Source: authors' compilation. TAM: technology acceptance model, PEOU: perceived ease of use, UTAUT: unified theory of acceptance and use of technology; PU: perceived usefulness; BI: behavioral intention; PE: performance expectancy; SI: social influence; FC: facilitating conditions; TTF: task-technology fit; AU: Actual Use.

\subsection{Perception of Performance}

The UTAUT model postulated performance expectancy (PE) as one of the strongest exogenous predictors of behavioral intention, being defined as "the degree to which an individual believes that using the systems will help him or her to attain gains in job performance" [36]. PE was conceived encompassing five root constructs from different models: perceived usefulness from TAM and the theory of planned behavior; extrinsic motivation from a motivational model; job-fit from a model of PC utilization; relative advantage from innovation diffusion theory; and outcome expectation from 
social cognitive theory. No matter the model, PE-related constructs remain the strongest predictor of intention [36].

Moreover, PE has significant effects on explaining the use of technology in both voluntary and mandatory settings [36]. This last PE feature uncovered two crucial aspects, especially relevant in an educational context. First, it makes the PE variable especially pertinent in lifelong learning, in either formal, non-formal or informal educational processes [22]. Second, the PE construct may be equated with learning outcomes in the case of educational technology [35].

\subsection{Social Influence}

According to Venkatesh et al. [36], social influence (SI) is defined as "the degree to which an individual perceives that important others believe he or she should use the new system." The SI construct is not exclusive of the UTAUT model, but its importance was previously represented as subjective norms (TAM2, theory of planned behavior, and the theory of reasoned action), social factors (model of PC utilization), and image (innovation diffusion theory). The UTAUT model put forward that the SI construct impacts behavioral intention. In a complementary manner, its positive effect on PE has been argued [37]. Additionally, Venkatesh et al. [36] posit that no matter the model, none of the SI-related constructs is significative in a voluntary context. However, they become significant in mandatory settings. In more specific terms, it has been argued that, in mandatory contexts, SI's impact on individual conduct could be attributed to a compliance mechanism, while internalization and identification mechanisms would alter an individual's belief structure, especially in non-mandatory contexts [36,38]. These postulates contrast with some research results that show a direct effect of SI on behavioral intention in cases of voluntary use of the YouTube platform [7,34].

\subsection{Hedonic Motivation}

In general, in the information systems discipline, utilitarian information systems, and pleasure-oriented information systems are differentiated [39]. Moreover, although there is vast literature derived from the TAM model that has focused on the utilitarian part of the use and acceptance of information technology, some more recent information technology acceptance models incorporate exogenous variables associated with hedonism $[39,40]$.

Hedonic motivation (HM) refers to the fun or enjoyment obtained by accepting and using a particular technology [41]. For more than two decades, authors point to hedonistic motivations as an explanation for the use of information systems [42,43] and, in fact, the positive effect of this variable on the intention or use of information technology has been supported in several contexts [44-47] and, in particular, to explain the use of social networking sites [48,49].

Since video platforms pioneer technologies in the integration of communication and video functions to create an interactive experience, the fun factor having a positive impact on their users' satisfaction [46]. In this sense, and from the perspective of learning, the study of Van Baalen and colleagues [47] notes that intrinsic motivations, such as attractiveness and fun, play an essential role in the acceptance of videos for learning, supporting the possible role of $\mathrm{HM}$ as an explanation of the use of videos in this context.

\section{Research Model and Hypotheses}

Based on the findings provided by the studies mentioned above in regards to SVPs, we propose the following hypotheses:

Hypothesis 1. The higher the performance expectancy, the greater the intention to use SVPs for learning.

Hypothesis 2. The higher the social influence, the greater the intention to use SVPs for learning.

Hypothesis 3. The higher the hedonic motivation, the greater the intention to use SVPs for learning. 
Figure 1 represents the research model of this study. In this research model, any increase in the levels of performance expectancy, social influence, or hedonic motivation causes an increase in the level of intention to use SVPs for learning. We propose the research model as an explanatory model, in the sense of testing the underlying causal relationships that can be generalized from the sample to users of SVPs for learning, and also as a predictive model, in the consideration of serving to predict the values of intention to use SVPs for the learning (IU) of new cases not included in the estimation process.

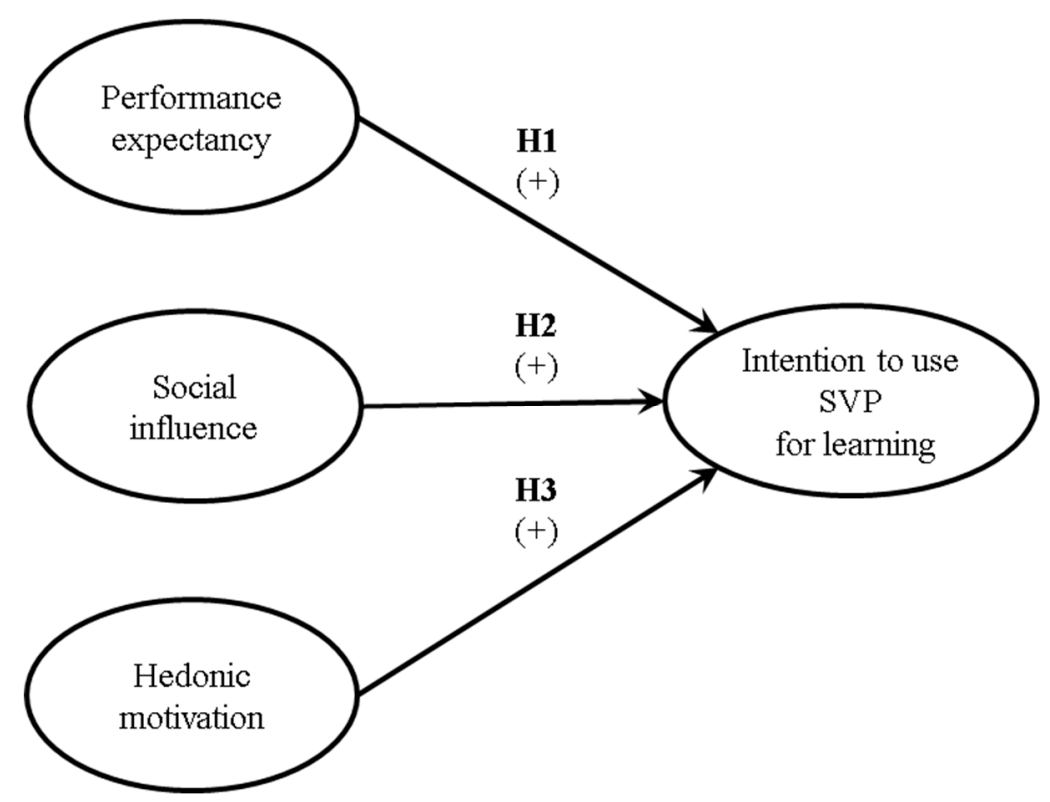

Figure 1. Research model. SVP: social video platform.

\section{Materials and Methods}

The empirical study was carried out between October and December 2018, in Brasilia, Brazil. The data was obtained through an online survey in Brazilian Portuguese, which involved a total of 568 YouTube users who use this SVP for learning. The respondents were 210 male and 358 females. Their ages ranged from 19 to 29 years. The respondents were informed that their answers would be kept confidential, and their participation anonymous.

The scales to measure the study variables were operationalized based on Venkatesh and colleagues [40]. A back translation process from the original scales in English to Brazilian Portuguese and then back to English was made to ensure semantic equivalence. Performance expectancy consisted of three items, like "Using YouTube for learning increases my productivity". To measure social influence, three items were used (e.g., "People who are important to me think that I should use YouTube for learning"). Also, hedonic motivation was measured with three items by the questionnaire; for example, "Using YouTube for learning is enjoyable". Finally, the intention of use was measured with the following two items: "I will always try to use YouTube for learning in my daily life" and "I plan to continue to use YouTube for learning frequently". All the items were measured using a 7-point Likert scale ranging from "strongly disagree"(1) to "strongly agree"(7).

The analysis of the explanatory model was based on the partial least squares (PLS) technique, and the PLSpredict algorithm was also used to assess the predictive power of the model. For these two purposes, the software SmartPLS 3.0 was utilized [50]. 


\section{Results}

\subsection{Assessment of the Measurement Model}

The first phase of the PLS analysis is the evaluation of the measurement model. Following Hair and colleagues [51], the results of this evaluation indicate that all measurements of the variables measured with reflective indicators are reliable and valid. Specifically, as Table 2 shows, all the indicator loadings with their latent variables are higher than the threshold of 0.7 and mostly higher than 0.9 ; the average variance extracted (AVE) is higher than the critical value of 0.5 , and all composite reliability coefficients have values above 0.9 .

Table 2. Assessment of convergent validity and internal consistency reliability.

\begin{tabular}{lcccc}
\hline \multicolumn{1}{c}{ Indicator } & Loading & $\begin{array}{c}\text { Composite } \\
\text { Reliability }\end{array}$ & $\begin{array}{c}\text { Average Variance } \\
\text { Extracted }\end{array}$ \\
\hline Performance expectancy & & & 0.919 & 0.791 \\
& PE1 & 0.904 & & \\
& PE2 & 0.887 & & 0.820 \\
& PE3 & 0.878 & 0.932 & \\
\hline Social influence & SI1 & 0.904 & & 0.889 \\
& SI2 & 0.929 & & \\
& SI3 & 0.883 & & 0.869 \\
Intention to use & IU1 & 0.938 & & \\
& IU2 & 0.948 & & \\
\hline Hedonic motivation & HM1 & 0.938 & 0.952 & \\
& HM2 & 0.928 & & \\
& HM3 & 0.930 & & \\
\hline
\end{tabular}

The discriminant validity was assessed based on the heterotrait-monotrait (HTMT) ratio of correlations [52]. As shown in Table 3, all the HTMT values are significantly lower than 0.90, which supports the existence of discriminant validity between measures.

Table 3. Discriminant validity analysis-heterotrait-monotrait (HTMT).

\begin{tabular}{ccccc}
\hline Latent Variable & PE & SI & IU & HM \\
\hline PE & $0.502(0.434 ; 0.567)$ & & \\
SI & $0.742(0.682 ; 0.794)$ & $0.620(0.545 ; 0.684)$ & \\
IU & $0.567(0.478 ; 0.643)$ & $0.364(0.285 ; 0.438)$ & $0.578(0.496 ; 0.652)$ \\
HM & Notes: numbers in brackets represent the $95 \%$ bias-corrected confidence intervals. \\
\hline \multicolumn{5}{c}{}
\end{tabular}

\subsection{Assessment of the Structural Model}

After the measurement model, the structural model was evaluated. Regarding the approximate adjustment measurements of the model, the standardized root mean square residual (SRMR) value of 0.05 complies with the recommendation of SRMR values less than 0.08 [53], this allows us to support that there is a minimum difference between the observed correlation and the correlation matrix implied by the model. The results of the bootstrapping procedure with 5000 samples indicate that all the relationships in the structural model are significant (see Figure 2). Specifically, and as Table 4 shows, PE $(0.409, p<0.001)$, SI $(0.296, p<0.001)$, and HM $(0.215, p<0.001)$ have significant effects on IU, whereas the coefficient of determination $\left(\mathrm{R}^{2}\right)$ of IU is 0.54 . 


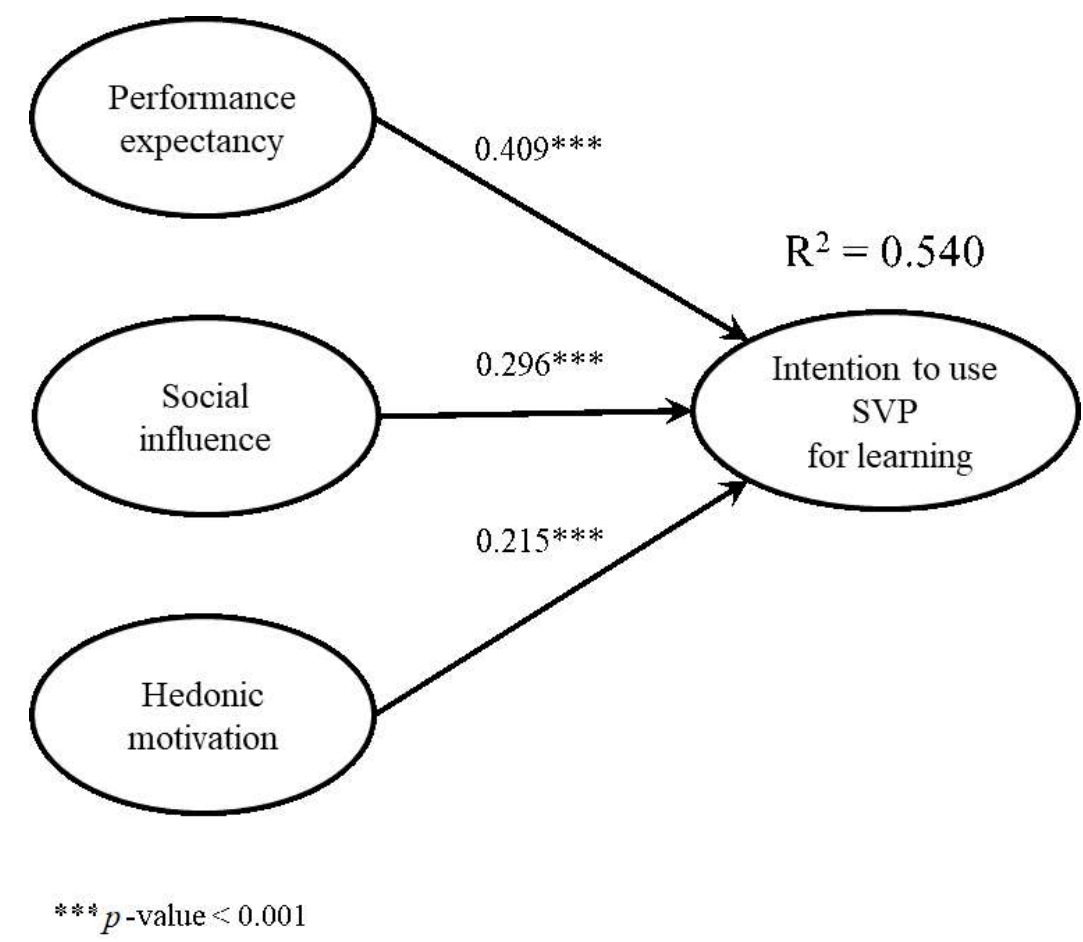

Figure 2. Partial least squares (PLS) results.

Table 4. Path coefficients and indexes of the structural model.

\begin{tabular}{ccc}
\hline Relationships/Indexes & Path Coefficients & $p$-Value \\
\hline $\mathrm{PE} \rightarrow \mathrm{IU}$ & $0.409(0.332 ; 0.483)$ & 0.001 \\
$\mathrm{SI} \rightarrow \mathrm{IU}$ & $0.296(0.222 ; 0.368)$ & 0.001 \\
$\mathrm{HM} \rightarrow \mathrm{IU}$ & $0.215(0.132 ; 0.294)$ & 0.001 \\
$\mathrm{R}^{2}$ of IU & 0.540 & \\
$\mathrm{R}^{2}$ Adjusted of IU & 0.537 & \\
$\mathrm{Q}^{2}$ of IU & 0.455 & \\
\hline
\end{tabular}

Notes: numbers in brackets represent the $95 \%$ bias-corrected confidence intervals.

\subsection{Out-of-Sample Predictive Power}

According to the guidelines of Shmueli and colleagues [54], the PLSpredict routine with ten folds and ten repetitions was used to determine how the PLS model would behave if applied to predict a new observation. Since PLS-SEM errors are distributed symmetrically, we base our predictive power assessment on the root mean squared error (RMSE). As shown in Table 5, for all the indicators in the analysis, PLS-SEM has lower RMSE values than the linear regression model (LM). Therefore, the model has a high predictive power.

Table 5. Path coefficients and indexes of structural models.

\begin{tabular}{cccc}
\hline \multirow{2}{*}{ Indicator } & RMSE & RMSE & (1)-(2) \\
& PLS-SEM (1) & LM (2) & -0.004 \\
IU1 & 1.275 & 1.279 & -0.009 \\
\hline
\end{tabular}

RMSE: root mean squared error; PLS-SEM: partial least squares structural equations modeling; LM: linear regression model. 


\section{Discussion}

This paper contributes to information technology acceptance research in two aspects. First, a research model was proposed and validated addressing the shortage of literature on the adoption and use of YouTube as a learning platform [9]. By doing so, our model explains and predicts the behavioral intention of using YouTube as an SVP for learning purposes. In this model, the utilitarian, hedonic, and social features coexist, the three of them being significant drivers of intention to use SVPs for learning. While other research works observed that hedonic motivation was a stronger driver than performance expectancy in non-organizational contexts [40], our empirical results suggest that PE is the construct with the highest effect on IU, followed by social influence and then the HM construct. This result posits that the utilitarian dimension remains the strongest predictor of IU in the context of YouTube as an SVP for learning. This finding contrasts with those reported in the hedonic information systems context, where ease of use and enjoyment show higher predictive power than perceived usefulness [39].

Furthermore, as mention above, our results exhibit a positive and significant effect of SI on IU, which is congruent with other results in voluntary contexts such as the use of YouTube for educational purposes $[7,34]$. In other words, end-users would have the intention to use the SVP for voluntary learning purposes when they perceive that important others-family members, friends, studying mates, and/or professors-value the adoption of YouTube for educational purposes.

These last observations lead us to suggest a broader implication related to the conception purpose of information systems. It should be the nature of a system's use (either utilitarian, hedonic, or both), defined or discovered by the end-users, which should address future information technology acceptance research.

As a second result, this research contributes to the assessment of the predictive power of an information technology acceptance model. In this sense, it is relevant to consider that the traditional PLS algorithm estimates the parameters as the average relationships and does not allow describing individual cases. Therefore, it is impossible to prescribe a specific decision. Predicting individual cases with PLS models allows extending the practical implications of the research, and that is the origin of the importance of the PLSpredict algorithm. In this sense, our study enables developing implications on how to increase the intention to use an SVP. In particular, we can indicate that any increase in the variables perception of performance, social influence, and hedonic motivation implies an increase in the intention to use for a new user outside the sample, with an effect proportional to the path coefficients associated with the relationships between those variables and the intention in the structural model. Nevertheless, we should note that the prediction evaluated by PLSpredict is associated only with items that measure intention to use, and not with the construct itself. Since a multi-item reflective scale is used to measure the intention to use, caution should be exercised if extrapolation of the results of this prediction is required at the construct level.

Since the study collected data from young YouTube users in Brazil, it is worth noting that the Brazilian higher education system, where these young people are real or potential students, is changing. Brazil's higher education system is the largest in Latin America. Recently and with rapid growth, private for-profit institutions have been established in this system; currently, these corporations manage one of the world's largest markets in private higher education for-profit [55]. In this context, quality assurance of Brazilian higher education is questioned [56]. The findings of this study indicate that utility is the most relevant explanation for the use of SVP for learning, and this could be associated, at least partially, to the search by users of content not delivered in an adequate quality by the institutions of the Brazilian higher education system.

Finally, although the ratio of the explained variance of the intention to use SVP for learning by the independent variables of the model is within the accepted range for this phenomenon [57], there is still an unexplained proportion. Therefore, we believe that it is necessary to continue in this line of work to increase this percentage. Among the new proposals to explore the adoption of information technologies, the moderation effects associated with personality types be obvious as an alternative, 
since there is evidence of their effect between performance expectancy and intention to use information technology [58].

\section{Conclusions}

Based on variables of information technology acceptance, this research examined the acceptance of SVP for learning. In particular, the study aimed to predict and explain the acceptance of SVP for learning based on three variables: performance perception, social influence, and hedonic motivation. The results indicated that $54 \%$ of the intention to use these platforms is explained. On the other hand, the analysis indicates that the structural model which explains this phenomenon shows a high predictive power. Since the empirical study was set in Brazil, and if we consider that quality education is a fundamental challenge to support sustainable development, these findings make it possible to implement these platforms for learning with a greater possibility of success and, therefore, to contribute to sustainable development in similar developing countries.

Author Contributions: Conceptualization, P.R.-C.; methodology, P.R.-C. and A.M.-M.; data collection: A.M.-M.; software, P.R.-C.; validation, P.R.-C.; formal analysis, P.R.-C.; investigation, P.R.-C., A.M.-M., and J.A.-P.; resources, A.M.-M. and J.A.-P.; data curation, P.R.-C.; writing-original draft preparation, P.R.-C., A.M.-M., and J.A.-P.; writing-review and editing, P.R.-C., A.M.-M., and J.A.-P.; visualization, P.R.-C., A.M.-M., and J.A.-P.; supervision, P.R.-C.; project administration, P.R.-C.; funding acquisition, A.M.-M. and J.A.-P.

Funding: This research received no external funding.

Conflicts of Interest: The authors declare no conflicts of interest.

\section{References}

1. Luo, L.; Wang, Y.; Han, L. Marketing via social media: A case study. Libr. Hi Tech 2013, 31, 455-466. [CrossRef]

2. YouTube YouTube. Statistics. Available online: https://www.youtube.com/yt/about/press/ (accessed on 26 September 2019).

3. Jenkins, H.; Carpentier, N. Theorizing participatory intensities: A conversation about participation and politics. Convergence 2013, 19, 265-286. [CrossRef]

4. Klobas, J.E.; McGill, T.J.; Moghavvemi, S.; Paramanathan, T. Problematic and extensive YouTube use: First hand reports. Online Inf. Rev. 2019, 43, 265-282. [CrossRef]

5. Taskin, Y.; Hecking, T.; Hoppe, H.U.; Dimitrova, V.; Mitrovic, A. Characterizing Comment Types and Levels of Engagement in Video-Based Learning as a Basis for Adaptive Nudging. In Proceedings of the European Conference on Technology Enhanced Learning, Delft, The Netherlands, 16-19 September 2019; Springer: Berlin, Germany, 2019; pp. 362-376.

6. Smith, A.; Toor, S.; Van Kessel, P. Many Turn to YouTube for Children's Content, News, How-To Lessons. Available online: https://www.pewinternet.org/2018/11/07/many-turn-to-youtube-for-childrenscontent-news-how-to-lessons/?utm_source=AdaptiveMailer\&utm_medium=email\&utm_campaign= 11-6-18Youtubecontent\&org $=982 \& l v l=100 \& i t e=3395 \& l e a=786826 \& c t r=0 \& p a r=1 \& \operatorname{trk}=\quad$ (accessed on 29 September 2019).

7. Jung, I.; Lee, Y. YouTube acceptance by university educators and students: A cross-cultural perspective. Innov. Educ. Teach. Int. 2015, 52, 243-253. [CrossRef]

8. Rosenthal, S. Motivations to seek science videos on YouTube: Free-choice learning in a connected society. Int. J. Sci. Educ. Part B Commun. Public Engagem. 2018, 8, 22-39. [CrossRef]

9. Chintalapati, N.; Daruri, V.S.K. Examining the use of YouTube as a Learning Resource in higher education: Scale development and validation of TAM model. Telemat. Inform. 2017, 34, 853-860. [CrossRef]

10. Davis, F.D. Perceived usefulness, perceived ease of use, and user acceptance of information technology. MIS Q. 1989, 13, 319-340. [CrossRef]

11. Buenaño-Fernández, D.; Gil, D.; Luján-Mora, S. Application of machine learning in predicting performance for computer engineering students: A case study. Sustainability 2019, 11, 2833. [CrossRef]

12. Pavel, A.-P.; Fruth, A.; Neacsu, M.-N. ICT and E-Learning-Catalysts for Innovation and Quality in Higher Education. Procedia Econ. Financ. 2015, 23, 704-711. [CrossRef] 
13. Zelenika, I.; Pearce, J.M. The Internet and other ICTs as tools and catalysts for sustainable development: Innovation for 21st century. Inf. Dev. 2013, 29, 217-232. [CrossRef]

14. Gregor, S. The nature of theory in Information Systems. MIS Q. Manag. Inf. Syst. 2006, 30, 611-642. [CrossRef]

15. Dumpit, D.Z.; Fernandez, C.J. Analysis of the use of social media in Higher Education Institutions (HEIs) using the Technology Acceptance Model. Int. J. Educ. Technol. High. Educ. 2017, 14, 5. [CrossRef]

16. Granić, A.; Marangunić, N. Technology acceptance model in educational context: A systematic literature review. Br. J. Educ. Technol. 2019. [CrossRef]

17. Scherer, R.; Siddiq, F.; Tondeur, J. The technology acceptance model (TAM): A meta-analytic structural equation modeling approach to explaining teachers' adoption of digital technology in education. Comput. Educ. 2019, 128, 13-35. [CrossRef]

18. Aburub, F.; Alnawas, I. A new integrated model to explore factors that influence adoption of mobile learning in higher education: An empirical investigation. Educ. Inf. Technol. 2019, 24, 2145-2158. [CrossRef]

19. Essel, D.D.; Wilson, O.A. Factors affecting university students' use of moodle: An empirical study based on TAM. Int. J. Inf. Commun. Technol. Educ. 2017, 13, 14-26. [CrossRef]

20. Manca, S.; Ranieri, M. Facebook and the others. Potentials and obstacles of Social Media for teaching in higher education. Comput. Educ. 2016, 95, 216-230. [CrossRef]

21. Kind, T.; Evans, Y. Social media for lifelong learning. Int. Rev. Psychiatry 2015, 27, 124-132. [CrossRef]

22. Yen, C.J.; Tu, C.H.; Sujo-Montes, L.E.; Harati, H.; Rodas, C.R. Using personal learning environment (PLE) management to support digital lifelong learning. Int. J. Online Pedagog. Course Des. 2019, 9, 13-31. [CrossRef]

23. Park, C.W.; Kim, D.-G.; Cho, S.; Han, H.J. Adoption of multimedia technology for learning and gender difference. Comput. Hum. Behav. 2019, 92, 288-296. [CrossRef]

24. Balakrishnan, V.; Gan, C.L. Students' learning styles and their effects on the use of social media technology for learning. Telemat. Inform. 2016. [CrossRef]

25. Ahmed, Y.A.; Ahmad, M.N.; Ahmad, N.; Zakaria, N.H. Social media for knowledge-sharing: A systematic literature review. Telemat. Inform. 2019, 37, 72-112. [CrossRef]

26. Balakrishnan, V.; Liew, T.K.; Pourgholaminejad, S. Fun learning with Edooware-A social media enabled tool. Comput. Educ. 2015, 80, 39-47. [CrossRef]

27. Khechine, H.; Lakhal, S. Technology as a double-edged sword: From behavior prediction with UTAUT to students' outcomes considering personal characteristics. J. Inf. Technol. Educ. Res. 2018, 17, 63-102. [CrossRef]

28. Wu, B.; Chen, X. Continuance intention to use MOOCs: Integrating the technology acceptance model (TAM) and task technology fit (TTF) model. Comput. Hum. Behav. 2017, 67, 221-232. [CrossRef]

29. Shoufan, A. Estimating the cognitive value of YouTube's educational videos: A learning analytics approach. Comput. Human Behav. 2019, 92, 450-458. [CrossRef]

30. Moghavvemi, S.; Sulaiman, A.; Jaafar, N.I.; Kasem, N. Social media as a complementary learning tool for teaching and learning: The case of youtube. Int. J. Manag. Educ. 2018, 16, 37-42. [CrossRef]

31. Shoufan, A. What motivates university students to like or dislike an educational online video? A sentimental framework. Comput. Educ. 2019, 134, 132-144. [CrossRef]

32. Lee, C.S.; Osop, H.; Hoe-Lian Goh, D.; Kelni, G. Making sense of comments on YouTube educational videos: A self-directed learning perspective. Online Inf. Rev. 2017, 41, 611-625. [CrossRef]

33. Lee, D.Y.; Lehto, M.R. User acceptance of YouTube for procedural learning: An extension of the Technology Acceptance Model. Comput. Educ. 2013, 61, 193-208. [CrossRef]

34. Bardakci, S. Exploring High School Students' Educational Use of YouTube. Int. Rev. Res. Open Distrib. Learn. 2019, 20, 260-278.

35. Sheppard, M.; Vibert, C. Re-examining the relationship between ease of use and usefulness for the net generation. Educ. Inf. Technol. 2019. [CrossRef]

36. Venkatesh, V.; Morris, M.G.; Davis, G.B.; Davis, F.D. User acceptance of information technology: Toward a unified view. MIS Q. 2003, 27, 425-478. [CrossRef]

37. Mehta, A.; Morris, N.P.; Swinnerton, B.; Homer, M. The Influence of Values on E-learning Adoption. Comput. Educ. 2019, 141. [CrossRef]

38. Dwivedi, Y.K.; Rana, N.P.; Jeyaraj, A.; Clement, M.; Williams, M.D. Re-examining the Unified Theory of Acceptance and Use of Technology (UTAUT): Towards a Revised Theoretical Model. Inf. Syst. Front. 2019, 21, 719-734. [CrossRef] 
39. Van der Heijden, H. User acceptance of hedonic information systems. MIS Q. 2004, 28, 695-704. [CrossRef]

40. Venkatesh, V.; Thong, J.Y.L.; Xu, X. Consumer acceptance and use of information technology: Extending the unified theory of acceptance and use of technology. MIS Q. 2012, 36, 157-178. [CrossRef]

41. Brown, S.A.; Venkatesh, V. Model of adoption of technology in households: A baseline model test and extension incorporating household life cycle. MIS Q. 2005, 29, 399-426. [CrossRef]

42. Davis, F.D.; Bagozzi, R.P.; Warshaw, P.R. Extrinsic and Intrinsic Motivation to Use Computers in the Workplace. J. Appl. Soc. Psychol. 1992. [CrossRef]

43. Igbaria, M.; Parasuraman, S.; Baroudi, J.J. A motivational model of microcomputer usage. J. Manag. Inf. Syst. 1996, 13, 127-143. [CrossRef]

44. Moon, J.W.; Kim, Y.G. Extending the TAM for a World-Wide-Web context. Inf. Manag. 2001, 38, $217-230$. [CrossRef]

45. Venkatesh, V. Creation of Favorable User Perceptions: Exploring the Role of Intrinsic Motivation. MIS Q. 1999, 23, 239-260. [CrossRef]

46. Liu, L.; Suh, A.; Wagner, C. Investigating communal interactive video viewing experiences online. In Proceedings of the International Conference on Human-Computer Interaction, Toronto, ON, Canada, 17-22 July 2016; pp. 538-548.

47. Van Baalen, P.; van Dalen, J.; Smit, R.; Veenhof, W. Utilitarian and Hedonic Motivations in the Acceptance of Web Casts in Higher Education. In Streaming Media Delivery in Higher Education: Methods and Outcomes; IGI Global: Hershey, PA, USA, 2011; pp. 247-268.

48. Ramirez-Correa, P.; Painen-Aravena, G.; Alfaro-Perez, J.; Mariano, A.M.; Machorro-Ramos, F. Motivaciones hedonicas para el uso de sitios de redes sociales por adultos mayores: Un estudio exploratorio en Chile. Rev. Iber. Sist. Tecnol. Inf. 2019, 17, 563-570.

49. Ramírez-Correa, P.; Grandón, E.E.; Ramírez-Santana, M.; Órdenes, L.B. Explaining the use of social network sites as seen by older adults: The enjoyment component of a hedonic information system. Int. J. Environ. Res. Public Health 2019, 16, 1673. [CrossRef]

50. Ringle, C.M.; Wende, S.; Becker, J.-M. SmartPLS 3. Bönningstedt: SmartPLS. 2015. Available online: https://www.smartpls.com/ (accessed on 25 September 2019).

51. Hair, J.F.J.; Hult, G.T.M.; Ringle, C.; Sarstedt, M. A Primer on Partial Least Squares Structural Equation Modeling (PLS-SEM), 2nd ed.; SAGE Publications: Thousand Oaks, CA, USA, 2016; ISBN 9781452217444.

52. Henseler, J.; Ringle, C.M.; Sarstedt, M. A new criterion for assessing discriminant validity in variance-based structural equation modeling. J. Acad. Mark. Sci. 2015, 43, 115-135. [CrossRef]

53. Hu, L.; Bentler, P.M. Fit indices in covariance structure modeling: Sensitivity to underparameterized model misspecification. Psychol. Methods 1998. [CrossRef]

54. Shmueli, G.; Sarstedt, M.; Hair, J.F.; Cheah, J.H.; Ting, H.; Vaithilingam, S.; Ringle, C.M. Predictive model assessment in PLS-SEM: Guidelines for using PLSpredict. Eur. J. Mark. 2019, 53, 2322-2347. [CrossRef]

55. Salto, D.J. To profit or not to profit: The private higher education sector in Brazil. High. Educ. 2018, 75, 809-825. [CrossRef]

56. OECD. Rethinking Quality Assurance for Higher Education in Brazil, Reviews of National Policies for Education; OECD Publishing: Paris, France, 2018; ISBN 9789264309050.

57. Rondan-Cataluña, F.J.; Arenas-Gaitán, J.; Ramírez-Correa, P.E. A comparison of the different versions of popular technology acceptance models a non-linear perspective. Kybernetes 2015, 44, 788-805. [CrossRef]

58. Ramírez-Correa, P.; Grandón, E.E.; Alfaro-Pérez, J.; Painén-Aravena, G. Personality types as moderators of the acceptance of information technologies in organizations: A multi-group analysis in PLS-SEM. Sustainability 2019, 11, 3987. [CrossRef]

(C) 2019 by the authors. Licensee MDPI, Basel, Switzerland. This article is an open access article distributed under the terms and conditions of the Creative Commons Attribution (CC BY) license (http://creativecommons.org/licenses/by/4.0/). 